\title{
Factors to Consider in Serologic Testing for Mycoplasma gallisepticum (MG) and Mycoplasma synoviae (MS) ${ }^{1}$
}

\section{G. D. Butcher, DVM, Ph.D²}

Serologic testing for MG and MS infections in commercial poultry is often confusing and difficult to interpret. However, it is imperative to know the Mycoplasma infection status of poultry flocks as this will influence decisions related to use of antibiotics, vaccination programing and biosecurity planning. Some factors to consider when testing for MG and MS infections follow.

Test systems commonly used include:

- Plate agglutination

- Hemagglutination inhibition (HI)

- ELISA (enzyme labelled immunosorbent assay)

Plate agglutination is a screening test and is prone to false positive reactions. It is possible to reduce false positive reactions by heating serum to $56 \mathrm{C}^{\circ}$ for 30 minutes or by diluting serum. False positive reactions are more common with $\mathrm{MG}$ than MS.

Factors associated with false positive plate agglutination reactions include:
1) Administration of inactivated vaccines that contain oil emulsions or virus vaccines prepared in cell culture supplemented with mammalian serum. Sampling should not be conducted after administration of vaccines that may cause false positive reactions. Such reactions occur from 2 to 5 weeks after vaccination and last for several weeks. False positives are particularly associated with Coryza and Gumboro oil emulsion vaccines.

2) Turbid, contaminated serum.

3) Sera that have been frozen and thawed prior to testing.

4) Cross-reaction of MS-infected birds with the MG antigen.

Plate agglutination can also give false negative reactions for MG and MS in cases of infection with avirulent or atypical strains that are poorly immunogenic. These strains are becoming more common in the commercial poultry industry worldwide.

Plate agglutination detects $\operatorname{IgM}$, while hemagglutination inhibition (HI) and enzyme

1. This document is VM126, one of a series of the Veterinary Medicine-Large Animal Clinical Sciences Department, Florida Cooperative Extension Service, Institute of Food and Agricultural Sciences, University of Florida. Original publication date May 1, 2002. Visit the EDIS Web Site at http://edis.ifas.ufl.edu.

2. Gary D. Butcher, DVM, Ph.D, Diplomate, American College of Poultry Veterinarians, University of Florida College of Veterinary Medicine, Gainesville, FL

The Institute of Food and Agricultural Sciences is an equal opportunity/affirmative action employer authorized to provide research, educationa information and other services only to individuals and institutions that function without regard to race, color, sex, age, handicap, or national origin. For information on obtaining other extension publications, contact your county Cooperative Extension Service office. Florida Cooperative Extension Service/Institute of Food and Agricultural Sciences/University of Florida/Christine Taylor Waddill, Dean. 
labelled immunosorbent assay (ELISA) detect IgG.

Thus, the plate agglutination test can detect seroconversion a few days earlier than the $\mathrm{HI}$ and ELISA.

Plate agglutination is not useful for detecting antibodies in egg yolk and maternally derived antibodies that are primarily IgG.

An HI or ELISA test is often used as a backup for suspicious plate agglutination reactors. These are not always sensitive enough as they are more strain specific and may not detect heterologous strains. The $\mathrm{HI}$ test is a difficult test to conduct as antigens are not commercially available. Many labs do not use HI today and are using the ELISA test.

Serologic reactions following use of the live MG vaccines needs to be understood. The live MG vaccines typically give poor serologic response. However, protection against MG is not related to serum antibody titer levels. Thus it may be difficult to determine effectiveness of vaccination. The 6/85 live MG vaccine typically will not cause seroconversion after six weeks following vaccination. Thus, serologic monitoring can be used in conjunction with this vaccine. 